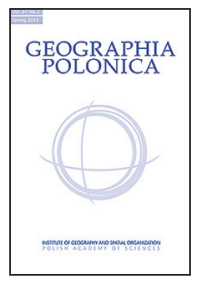

\title{
AN OUTLINE OF BORDER CHANGES IN THE AREA BETWEEN THE BALTIC AND THE MEDITERRANEAN: THEIR GEOPOLITICAL IMPLICATIONS AND CLASSIFICATION
}

\author{
Jernej Zupančič ${ }^{1}$ • Jan A. Wendt ${ }^{2}$ - Alexandru llieș \\ ${ }^{1}$ Department of Geography, Faculty of Arts \\ University of Ljubljana \\ Aškerčeva 2, SI-1000 Ljubljana: Slovenia \\ e-mail: jernej.zupancic@ff.uni-lj.si \\ ${ }^{2}$ Institute of Geography, Faculty of Oceanography and Geography \\ University of Gdańsk \\ Bażyńskiego 4, 80-309 Gdańsk: Poland \\ e-mail: jan.wendt@ug.edu.pl \\ ${ }^{3}$ Department of Geography, Tourism and Territorial Planning \\ University of Oradea \\ Universitatii st., 410087, Oradea: Romania \\ e-mail: ilies@uoradea.ro
}

\begin{abstract}
This article deals with changes in political boundaries, border regimes and border policies that have taken place in the area between the Baltic and the Mediterranean, which corresponds in the broadest sense with the term 'Europe-in-between'. An important generator of problems here has been the multi-ethnic composition of the population, a source of diffuse political processes often even giving rise to conflict. Border policies have served as indicators of the relationships pertaining between countries, though they have an even broader exponent relating EU policies and peacekeeping missions, among other things, and thus offering nothing less than a laboratory for geopolitics both old and new. In the three parts present here, the first represents a short theoretical discussion concerning national systems, while the second offers an empirical analysis of border changes and policies in the area stretching from Kaliningrad to the Bosphorus and Trieste. Finally, a third, synthetic, part discusses recent challenges to border policies in the area in question posed by processes of European integration, as set against the new security paradigms of our era. Particular emphasis is placed on strong immigration pressure, pan-Turkish strategic aspirations, the Balkan area and its policies and the relationship between the EU and Russia.
\end{abstract}

\section{Key words}

border politics $\bullet$ border changes $\bullet$ Central and Eastern Europe $\bullet$ security $\bullet$ new geopolitics 


\section{Introduction and theoretical approach}

After Communism fell in 1989 and the years beyond, a bipolar world of East-West relations leaned in the direction of (Euro-American) unilateralism. The construction of a united Europe as one of the cores of global economic power took two decades to enlarge in an eastern and south-eastern direction, via a process that saw (Western) European norms and rules of economic and political relations implemented in most of the transition countries present in the area between the Baltic and the Mediterranean. This space had once served as a cordon sanitaire and then as a European shatter belt (Tunjić 2006: 153). Overall, it is is strategically important territory lying between the maritime rimland and the continental heartland (Parker 1997). Capable of serving as key indicators of geopolitical dynamics in this region are changes in political boundaries, as well as the culmination and fluctuation of border regimes and border policies during periods of political equilibrium.

A key premise of political development concerns the relationship between elements of power (be it economic, political, military or cultural) and the interests that these forces lead. Formal-political regulations are secondary and adapt to needs. For nearly two decades, Euro-Atlantic integration inspired an ideal-political developmental vision of the world (seeing political relations as a product of the law, and basing itself on the postulates of democracy (the will of the people), as well as humanism (the main raison d'être policy skills forming part of the general or public good). However, the confrontation and disparate strategic interests manifested by the EU and USA, especially in the circumstances of the election of President Donald Trump, and the situation in Russia, the matter of the refugee-migrant influx and consequent migration crisis, the British Brexit and neo-Ottoman political pretensions have all served to reveal the fictional nature of the above ideal-political vision. Indeed, it becomes clear that geopolitical relations have all the time remained based on the balance of power and interests.

This article seeks to analyse changes in political borders, border regimes and border policies in the whole area between the Baltic and Mediterranean Seas. In the near past, this area represented a kind of gateway region between Central, Southern and Eastern Europe, but today it is facing both European integration processes and the new security paradigm. The result is a picturesque recent political map, on which almost all types of European country can be found. There are EU and NATO Member States, EU candidates, CIS countries, states under international protection (or what are virtually UN protectorates), para-states and other polities based around provisional territorial solutions. This large geographical sphere can thus be treated as little less than a real-life laboratory for the old and new geopolitics.

The first group of factors involves countries seen from the point of view of border creation and border policies. A border is an extreme outer edge of a country, with the latter seeking to determine the course of the former, furnishing infrastructure, and exerting a direct impact on of the way border space is structured and the policies that are pursued there (Ganster \& Lorey 2005). In the past, border areas might be passive, and extra-dependent on directions set by governments whose policies were mostly centralist in character. Borderlines as such were surveilled by the military, police, border guards and the customs authorities (Brown et al. 2001). Border crossings were relatively rare and took place in the presence of a high level of outfitting in infrastructure (Ganster \& Lorey 2005: 25-38).

The fact that ethnic minorities were often present in border areas had its key place among the factors exerting greatest influence on border policies in countries of the so-called 'Europe-in-Between'. Ethnocentralistic policies encompassed minority assimilation processes, given the representation of minorities as capable of posing political and/or security risks of some kind. Peripherality of areas was in part therefore due to (even maintained by) 
such efforts, reflecting views whose extreme versions saw minorities represented as 'fifth columns'.

Such anti-minority policy intensified in the inter-War period and obviously culminated in the atrocities of World War 2, before in some sense continuing (albeit in somewhat changed form) in the post-War decade. That period in fact saw many ethnic minorities resettled in line with an objective that security measures should this time be pursued proactively. Led by prevalent security premises, authorities fortified ('bunkerised') borderlines with defensive systems, as well as taking various measures relating to the economy, education, public administration and culture, and seeking in general to reinforce the presence of state institutions in border areas. There might well be certain spheres of government (like the police force, armed forces, customs authorities, educational system and public administration) in which it was mostly members of the ethnic majority that were employed. The instrumentalised border was reinforced by cultural and economic moments, and border areas tended to become poor economically, structured in a peripheral manner and hence in practice condemned to a status of increased dependence on the core area within each given state.

Emerging in marked contrast to all of the above was a European integration process that implemented and stimulated policies of cross-border cooperation and integration. Border areas came to be known for their new local, or much broader initiatives, with border controls curtailed, exchanges promoted, and cross-border ties put in place (Bufon et al. 2014:11-22). Where the common European economic space (put in place by the Schengen Treaty post-1987) is concerned, border monitoring has effectively been eliminated entirely. Admittedly, this entailed the identification of an external frontier along which surveillance, monitoring and enforced security measures have if anything increased.

However, this mixed circumstance of borders being either less (or occasionally more) tangible than before needs to be treated somewhat separately from the issue of the nationalisms and ideologies that have been the essence of the state in the past and may still be a major raison d'être for the state's establishment and existence (Hobsbawm 2001: 23-29). Even today, the countries contained by borders do differ, and do even prize the aspects that make them different. This remains true of the vast majority of European countries (White 2007), and is an entirely consistent factor in the 'Europe-in-between' that is the subject of this paper. Where borders as lines on the ground may be indistinct, nationalism may paradoxically play the role of major risk factor, seeking as it does to identify ethnically homogeneous territory. For at least a century and a half this same motivation was the leading spiritus agent underpinning actual changes in political boundaries (Horowitz 2002), though several different stages of integration and fragmentation have been passed through over the course of recent history.

Notwithstanding all of the above, it is clear that integration in alliances has constituted a second set of factors, in which the underpinning motivation relates to common economic, cultural or security-related factors. Once again, the edge regions of such an alliance assumed a kind of importance, given their main function of defending and ensuring the security of all allied member polities. This left pressure to pursue policies ensuring greater security as the absolute dominant (Gilpin 2001:12-25). In this case we are dealing with geopolitical macrostructures comprising cores and hinterlands. While the latter changed the geopolitical specific weight, impact and extent, the maritime zone was widely more fluctuant. Some political entities has been created and another leave the political scene (Link 1998).

Another feature has been the appearance of small countries as a reflection of fragmentation effects operating at geopolitical intersections. This is particularly reflected in the case of Yugoslavia. The Multiethnic Socialist Federation pursued a policy of non-alignment during the Cold War Era leaving it in a position as a potential gateway region, which ensured that the continental heartland (comprising the communist states of Central and Eastern 
Europe, together with Soviet Union) as an almost a landlocked area, given the way that access to the wide open Adriatic aquatorium was impeded. At the same time, this situation put an obstruction through the political West, given the way it separated Italy and Greece as maritime countries and fellow members of NATO. The North-Mediterranean arc was thus cut across by the specific position of Yugoslavia. These broader geopolitical relations had a strong impact on border policies given the way that supervision of almost all border areas was increased.

With the disintegration of both the Yugoslav federation and the Soviet Union (1989 to 1992), the entire space of 'Europe-in-between' became fragmented, but also experienced further peripherisation. New nation states created in this way underwent a strengthening of their ethnic and territorial identity, even as their existence contributed to the strategic weakening of this European region as a whole. Ethnic warfare in Yugoslavia (Pirjevec 2003) led to the development of a wide area of conflict zones, and this only served to expand the range of what might be regarded as peripheral still further. International policies of intervention in the most critical hot-spot areas left space further fragmented, and for a long period of time. The regional 'cores' became areas of crisis urbanisation, with the normal effect that hinterland areas were left very weak and limited. Some parts were simply emptied of population through genocidal wartime activities and later resettlement, and/or because of the unfavourable economic conditions arising. Most of the zones that experienced intensive military conflicts in the past still retain their minefields, and this precludes almost all possible forms of economic utilisation. The narrow contact zones in turn came under international military and political control, while other space served the military in the role of camps, training areas, storage and technical infrastructural support. While international security forces may have been serviced in this way, new internal borders were effectively established by the process. In turn, the wasting of space took place in urban and suburban zones, due to uncontrolled processes of agglomeration and an attendant lack of spatial planning, with this even leading to the emergence of slums in some localities (Vöckler 2008). Ethnic enclaves remain as areas of crisis-agglomeration, and they suffer from particular problems. Surrounded by a non-cooperative majority, they try to organise all necessary services for themselves (Zupančič 2015).

All of the above cases demonstrate perfectly the regressive development in political peripheries and associated deepening of social problems that may most likely only prove resolvable over any shorter period if state economic and social interventionism is resorted to, the principle being the same for these areas as for border regions. Everything has already been seen before, i.e. controlled spaces, protected areas (National Parks, etc.) and other particular intervention measures and policies. The ethno-centralist orientation of nation states remains the main content of the relationship between core and ethnically-diverse border areas, but the forms or types of border policies are adapted to recent circumstances tactically. In the case of the Balkans in particular the prospect of integration processes is burdened, not only by past conflicts, but by an even more pronounced peripheral structure. These areas have very little endogenous development potential (Zupančič 2015: 203-210).

The third characteristic of this group of factors is that the rules and norms are determined by the core geopolitical units, while the marginal countries have been followers and have simply had to implement these rules. In these ways, marginal areas had to come to tactical adjustments and to numerous compromises many times (Czempiel 2003). It is expected that the political map in this wide area of 'Europe-in-between' is predestinated to experience frequent border and border-regime changes, ensuring the generation of a picturesque political mosaic.

A third set of factors operates primarily in an indirect way, though the effect exerted on public opinion, conscience and identity. It embraces network connections at local level. A border area has mosaic rule, at least at the 
outset. It is inhabited by minorities for whom the ethnic core is in another, neighbouring country, but the political and economic ties remain with the current political and territorial framework. Minorities are also torn between the formalist pragmatism of belonging to a legal framework (country of residence) on the one hand and, on the other, the interests of cultural action and ethnic survival that tie them to another country (Conversi 2007: 272-284). These circumstances leave minorities assigned to various positions and roles. Quite commonly, they are even considered risk factors, to the extent that the policies of nation-states have even sought to reduce or eliminate them. Only in the last few decades have states sought to integrate minorities, at least at the level of public declarations. On the other hand, minority situations have been resolved via bilateral or multilateral agreements. Hence minority protection is primarily the product of diplomatic and political sublimation (with the granting of minority rights favoured over acquiescence to territorial demands), though also to a lesser extent reflects humanistically-oriented relations pertaining between the majority and the minority (Zupančič 2005: 28). However, there are such practices to be noted, and this represents a very important political heritage of Europe. The minorities living along a border can help increase cross-border cooperation significantly, and some minorities maintain an extensive network of contacts representing integration potential. However, this is not, unfortunately, the general case. Indeed, the minority potential in many nation-states is less exploited than it could be. Old ethno-centralist ideals still have considerable influence and power under the new conditions characteristic of European integration processes. Ethnic minorities continue to face various forms of ignorance or even pressures, though attitudes towards them seem much better than was the case a few decades ago, probably due to the far-reaching atmosphere characterising common European space. While this is clear on a declarative level, it is much less followed by bilateral practice (Zupančič 2006).

\section{Methodological work}

Given the very wide geographical research area between two peripheral inner-continental seas, i.e. the Mediterranean and the Baltic, it is necessary for analysis to be limited to the observation of territories and policies in macrostructural terms. Detailed case studies can only be invoked to a limited degree. The methodology of this work is thus dominated by comparative methods related to older and recent leading policies, ideologies and predominant political, economic, cultural and security structures and processes. Comparisons relate to the balance and relationships between individual units (mainly states). The other main method is the interpretation of recent structures, processes and policies, as well as retrospective interpretation of older geopolitical features in the wide area of 'Europe-in-between'. Sources for this can be found in available documents and there are many cases already explained by other authors in the literature.

The selected territory is of large size, and is varied from the natural and human perspective. However, it has some very common features, in terms of the mode of political development, whereby political borders changed relatively more often than in the western or northern parts of Europe, and often reflected foreign (external) factors. In these contexts, border policies and regimes seem to be the consequence, done primarily from inside, from within countries and their political authorities. The region as such is not the leading influence. The wider context includes the geopolitical framework and laves the region under the influence of continental forces at some times, and of maritime forces at other times. This reflects perfectly the competition between the maritime rimland and continental heartland.

Methodological approaches rely on three key premises by which to identify the key factors affecting the formation of political boundaries, creating border regimes and ensuring that various functions of political boundaries are maintained in the area. These include challenges in regard to the way in which 
national systems based on the structure of the territory (ethnic composition, economic policies, regional policies, etc.) affect border regimes and policies; as well as the influence of broader external policy on countries in that area. In the studied case, what are involved in particular are the EU and NATO on the one hand and the CIS on the other. And hence, given that boundaries in this area have changed dynamically, while borders under communism were mostly closed, how does historical memory and political tradition impact on border policy.

The basic objects of the analysis are political boundaries and the dynamics characterising their transformation by factors assigned to three groups in line with the manner and direction of their effects, i.e. factors, sourcing from state systems and territorial structure. What are included in this context are policies and ideologies implemented or pursued by these countries, and bearers or subjects of them; factors relating to international operations, primarily international political, economic and security associations (such as the EU or the CIS in the economic sphere and NATO in the military and security sphere), but also strong individual countries capable of proving influential in the research area; and factors relating to political traditions and collective historical memory. Specifically then, it was on the basis of an analysis of relations and geopolitical conditions as of 2016 that the classification of geopolitical factors determining the evaluation of borders as barriers or conveniences in international relations was engaged in.

\section{The main issue of Baltic and Eastern European borders}

As a consequence of 1989-1990 events taking place in Central and Eastern Europe, this region and its countries have experienced a complete change of geopolitical situation. The 1989-1991 period brought an extremely rapid disintegration of the Soviet Union's 'outer empire', with Czechoslovakia, Poland and Hungary achieving full sovereignty. In East
Germany (the GDR), in turn, a process leading to reunification with West Germany (the FRG) took hold. A year later, due to the dissolution of the Soviet Union as a unified state, as well as the disintegration of Czechoslovakia and the successful German reunification, the geopolitical position of Poland and other countries within the region was changed markedly. Poland experienced the fastest ever recorded change of all neighbouring countries, (for this first time) without any alteration whatsoever of its territory and boundaries. In short, in place of the three countries that had been adjacent to Poland in 1989, the country post1990 has acquired common borders with the seven states of Russia, Lithuania, Belarus, Ukraine, Slovakia, the Czech Republic (latterly Czechia) and Germany.

Besides the changes along the Polish borders, other meaningful changes in economic and political links within Europe have also occurred. Following a period of dominance over Central and Eastern Europe dating back to the times of Catherine the Great (with a short 1917-1939 interval), Russia returned to Eastern Europe, leaving the country to successor states of the former USSR enjoying varying different levels of independence (limited in many former republics by persisting economic links, or even by the ongoing presence of Russian garrisons on their territories). In Sevastopol, which was located on Ukrainian territory in Crimea until the outbreak of hybrid warfare there in 2014, a Russian naval port and base had been functioning steadily together with Ukrainian naval port. Two further military bases of Russia, Hancavičy Radar Station and Volga-type Radar are located in Belarus.

The problem of a not-precisely-delimited border between Estonia and Russia is still not resolved despite a treaty concerning the borderline between those countries, as well as delimitation within the Gulf of Finland and Narva Bay, having been signed. Additionally, Russia keeps accusing the Estonian authorities of harassing the Russian minority within the country, despite the fact that this issue was resolved in 2015, through the adoption of new amendments to the Citizenship Act. 
Just like Estonia, Latvia is also bearing from problems associated with the Russian minority and the way Russia perceives their situation. During the discussions concerning Latvia's membership of the European Union, Russia lodged a formal objection against the way the country treats human rights in the context of supposed persecution of the Russian minority, which was forced to learn the local language - according to the Russian Ministry of Foreign Affairs. Like its neighbor to the north, Latvia also had problems recognizing the border with Russia. The same Russia, which could not agree to leave the region (Pytalovo/Abrene) inhabited almost entirely by Russians within Latvia. This problem was resolved by the signed and ratified treaty of 2007, in which the disputed region was located within Russia. Even though the Estonian-Russian and Latvian-Russian borders are acknowledged officially by both sides, the relevant delimitation process has not ended. The Latvian authorities are concerned at Russia's objection to the determination of the official borderline, as it uses the argument of a lack of funds as an excuse to delay the process. Only the Lithuanian-Belarusian border fails to generate diplomatic discussions between the respective countries. However, the lack of properly-developed cross-border transport infrastructure and the new executive regulations introduced by Russia at the end of 2015 in regard to road transport have caused tangible financial losses for Polish and other EU transport companies, and also created long queues for trucks crossing the EU borders with Russia.

The issue of Poland's eastern and northern borders represents a major problem for Polish international cooperation, not only because of Poland's status as a transit country (Wendt 2001), but also - mainly - because of the fact that a large Polish minority remained beyond the new borders of Poland after 1945 (Barwiński 2013). An additional issue is the development of, and drawing of benefit from, cross-border tourist traffic with the east, which recorded a marked increase following Poland's accession to the EU (Wendt 2010). A Polish eastern border that is also the eastern frontier of the entire EU is also a factor playing its role in the diffusion of systems, institutions and democratic standards capable of effecting domestic change among eastern neighbour states of the European Union (Wendt 2002). Poland signed agreements on local border traffic with Ukraine (2008), Belarus (2010) and Russia (2011). The agreement signed in 2008 with Ukraine only came into force in 2009, due to objections expressed by the European Commission, while the agreement with Russia (Kaliningrad Oblast) was in effect from 2012. The agreement with Belarus dating from 2010 only actually started to function at the end of 2016.

The main problems connected with the eastern and northern borders of Poland reflect the dual status as external frontier of the EU, but also the foreign policy pursued by the Russian Federation. Above all, Polish foreign policy experiences constantly strained relations with the Russian Federation. Indeed, Russia's foreign policy in Ukraine is seen to pose a genuine threat to Polish security - in a direct sense, given the occupation of Crimea by Russia, and also as regards energy, given Polish dependence on Russian gas and oil (BieńczykMisala 2016). Another major issue is the large scale of the economic migration to Poland engaged in by citizens from Ukraine mainly, but also from Belarus. This reaches its peak in the summer season each year, and is estimated to involve around one million Ukrainians residing and working in Poland (both legally and illegally). Economic migration into Poland was obviously intensified following the outbreak of hybrid warfare in Ukraine. This has meant an increasing number of Ukrainians in Poland applying for actual refugee status, given the political situation in Ukraine. Furthermore, Ukraine remains the main transit country for both CIS and non-CIS irregular migrants aiming to reach the EU via its eastern borders. In addition, Ukraine also offers the major route for migrants from the Caucasus region and Central Asian countries travelling towards (or from) the Russian Federation. It remains difficult to ascertain the extent to which 
these twin flows are linked (Eastern Borders ... 2012). Another issue is the lack of a solution when it comes to transit traffic between Russia and Poland, as well as the EU. Since the 1990s, Russia has been blocking navigation through the Strait of Baltiysk periodically. This problem of navigation has even led Poland to begin considering the excavation of a canal across the Vistula Spit.

Local border traffic with Ukraine has worked without any major problems since the common organisation of the UEFA European Football Championship in 2012, but because of the weakness of border infrastructure on the Ukrainian side, large traffic jams on the Poland-Ukraine border have kept arising. Like the border with Ukraine, the PolishBelarusian border is also seeing the development of shopping-based tourism. On the Polish articles of all kinds, up to and including food and clothing, are being bought. In turn, Poles abroad, mainly in Russia, buyfuel, while importing - or smuggling - cigarettes from Belarus, Russia and Ukraine.

A separate issue is the so-called "small border traffic" with Russia's Kaliningrad District, which is a consequence of the development of Russian shopping tourism. Unfortunately, like all relations along the Polish-Russian border, this is nearly entirely dependent on the decisions of Moscow. In response to the economic sanctions imposed on Russia (as punishment for the seizure of Crimea, and the hybrid warfare being waged in Ukraine), Russia has limited trade with the EU countries, mainly Poland. Poland exporting vegetables and fruits to Russia was significantly affected by the Russian embargo (drop in exports by $30 \%$ in 2015). However, the overall fall in trade in goods with Russia has also included EU sanctions. The Russian economy slowed down, the ruble value against the dollar and the euro fell, and thus the Russian imports decreased (Nacewska-Twardowska 2015: 228). On the Polish-Russian border within the framework of local border traffic in the first quarter of 2016 the Border Guard recorded 251.1 thousand, ie $20.9 \%$ less than in the fourth quarter of 2015 and $7.0 \%$ less than in the comparable period of 2015. Estimated value of expenses incurred in Poland by foreigners crossing the Polish-Russian border within LBT in the first quarter of 2016 has decreased by $35.7 \%$ compared to the previous quarter and was $23.9 \%$ lower than in the first quarter of 2015. (Ruch graniczny ... 2016). Kaliningrad District, formerly one of the most militarised regions in Europe, became an area of intensive Polish-Russian cooperation post-1991 (Wendt 2004). Forecast growth in criminal activity did not really pan out, though there has been a slight increase in incidents involving Russian citizens, if not in any way proportional to the increase in numbers of crossings made (Dudzińska \& Dyner 2013).

\section{Main problems of the borders between the Carpathians and the Bosphorus}

The eastern boundaries between the Carpathians and the Bosphorus have reflected major territorial changes since WW1. After the second Balkan War in 1913, Romania won South Dobruja (Dobrogea) (Gerolymatos 2002: 125-140), as well as extending its territory into Ciskarpathia, large areas in the east in Bessarabia and northern Bukovina (Wendt 2004). Hungary was limited to the central part of the Pannonian Plain, while north of them the composite country of Czechoslovakia was established (Crampton 1997). After WW2. Ukraine reached the Pannonian Plain and gained parts of Bukovina and Bessarabia (Ilieș \& Wendt 2014). In the main part of the former Bessarabia Moldavia and then new Republic of Moldova took shape (King 2000).

External borders did not change officially following the fall of the communist regimes in 1989 (Sebestyen 2009). However, inside these borders there has at times been territorial fragmentation due to the activity of ethnic rebels. With the acquiescence of Russia, a transformation of Russia's 14th Army into an autonomous force took place in Moldova. This acted in support of the secessionist aspirations of Transnistria in its conflict with Moldova, leading to the establishment of the 
Pridnestrovian Moldavian Republic on the territory of eastern Moldavia. Under Russian influence, a de facto independent Transnistria was formed, though this has continued to go unrecognised internationally (Hupchick \& Cox 2001), other than by Russia and Ukraine, which recognize its de facto existence. Gagauzia declared independence (19.08.1990) as an enclave-country within Moldova, while certain political parties in that same country have sought opportunities for a reunification of Romania and Moldova to proceed. At the end of 1994 the Parliament of the Republic of Moldova adopted the "Gagauz Yeri Special Law Act". This Unionist movement proved to lack sufficient support, while an additional obstacle was also the staunch Russian and Ukrainian opposition to the idea.

Like Ukraine, Moldova post-2013 faced questioning of its pro-European orientation (Derlaga \& Wendt 2006: 141-158), given that Russia regards this too as a potential contraction of its are of influence. Romania and Ukraine also had an open maritime dispute over the continental shelf in the Black Sea, though this was in practice solved by court proceedings involving international maritime law (in 2009), with the principle of equidistance being applied.

Romania and Bulgaria are confronted by expectations regarding territorial and cultural autonomy for large minorities residing there. The issues with minorities are affected by countries of origin (notably Hungary and Turkey), with historical hegemony in the recent past being an issue in each of those cases. The tensions associated with these circumstances tended to reduce the level of cross-border cooperation

The borders in question were simply closed during the communist era, with the crossings that did exist being few and far between, and subject to heavy control. Romania and Bulgaria did not even share a bridge over the Danube until the turn of the millennium, while riverside towns and cities knew almost no kind of cooperation at all. The largest European river was a channel for traffic, but also an effective natural fence. When communism ended, liberalisation of this cross-border communication became one of the first measures, and was imbued with great symbolic significance (llieș et al. 2007). However, despite numerous European initiatives and projects, the level of cross-border cooperation here remains modest. Moreover, the border region is itself passive, with few bottom-up initiatives appearing (Ilieș et al. 2011).

The eastern borders of Slovakia and Hungary with Ukraine are again external borders of the Schengen Area, while Romania and Bulgaria could have normal border controls one with the other. However, much of the border of these countries are with the non-EU Member States of Serbia, Moldova, Ukraine, Macedonia and Turkey. These boundaries thus act as economic and security filters for the EU.

The western part of the Black Sea and Balkan-Carpathian arc have faced huge challenges over the last decade, due to the evolution of political processes, and especially the war in Ukraine and large immigrant influx. Securisation of the EU's external borders has become a key dominant in the instrumentalisation of political borders as a necessary consequence. The closing of borders with razor-wire fences has become common practice over large areas from the Black Sea coast to Edirne, from lower part of the River Maritsa to the Aegean Sea, as well as along the Hungarian and Slovenian borders.

\section{The borders between the Upper Adriatic and the Aegean}

Political and territorial development in the Balkans following the fall of communism was guided by nationalism. The multiethnic Yugoslav federation disintegrated and new nationstates formed. The Bosnian nation was newly formed on the basis of the old Muslim cultural substance within the territorial limits of the historical Bosnia and Herzegovina. Although it is most of the causes of the emergence and development of the Yugoslav crisis due to ethno-nationalism (and mistakes of political management with him at the international diplomatic level) (Banac 2006: 34-43) have means 
of resolving the Yugoslav crisis characteristic features of the compromise handling at the intersection of forces rimland and hartland.

In Croatia, the period from spring 1991 onwards saw the formation of a Serb rebel territory covering around $17,500 \mathrm{~km}^{2}$. Supported by the residual Yugoslav Army and Serbian volunteers, this para state existed until the summer of 1995, being terminated by Croatia's 'Storm' military offensive (Tanner 1997). The area remained largely emptied demographically, with a destroyed infrastructure and contamination by mines.

In Bosnia and Herzegovina, the presence of temporary refugees gave rise to ethnic enclaves (Burg \& Shoup 2000). These refugee cores have contributed to post-war crisis urbanisation. 'The Dayton Peace Accord (of 1995) brought an end to the war, with external political boundaries retained, while internal movement and deferrals are arranged with a unique administrative and political arrangements between two entities within B\&H: the centralist Republic of Serbia and the Bosnia-Croat Federation, composed of cantons. Brčko District represents a specific unit directly under the government of $\mathrm{B} \& \mathrm{H}$. Internal political boundaries were adjusted in line with cease-fires and ethnic polarisation. Ethnically mixed cantons are de facto divided along ethnic lines (Pirjevec 2003). The country is an international protectorate. After the NATO airstrikes against the Federal Republic of Yugoslavia in 1999, the situation in Kosovo led what was formerly a Serbian province to come - and remain - under the international supervision of NATO and EULEX. A Serb population continues to live in ethnic enclaves. The largest of these (North Kosovo) makes contact with Serbia in territorial terms, and acts as a de facto part of Serbia. Kosovo declared independence in 2008, but Ahtisaari's proclamation of the concept of a multi-ethnic Kosovo is a complete illusion (Zupančič 2015). The Albanian uprising in Macedonia in 2001,

1 The best example of the crisis regarding urbanisation is Priština, Kosova's capital (Vöckler 2008). Kosovska Mitrovica is in turn the perfect case of a divided city (Zupančič 2015). and the Ohrid Agreement done under the strong influence of the EU and the US ensured major participation for the Albanian community (e.g. a one-third share of administrative structures) where the governing of Macedonia is concerned. in any case, Western Macedonia acts a particular territory de facto; even as a para-state.

In the Balkans, some nations live formally in two (or more) countries or political units. Croats live in Croatia and two ethnically homogeneous cantons of Bosnia and Herzegovina, Serbs in Serbia and the Republic of Serbia within Bosnia and Herzegovina, and additionally de facto in North Kosovo. Albanians have two Albanian countries: Albania and Kosovo as well as de facto Western Macedonia, as a para state. In turn, Greeks inhabit two countries (Greece and Cyprus) and Romanians likewise (Romania and Moldova), while the Turks have Turkey and the Turkish Republic of Northern Cyprus (Zupančič 2009: 122-125).

After the proclamation of statehood, the borders between the former Yugoslav republics began to operate primarily as obstacles. Due to war-stories in the near past and international sanctions (in Serbia), border relations have developed specific forms of border corruption, smuggling, an informal economy and other kind of illegal economic and cultural life. Establishing new rules in marginal areas and changing the situation as regards these negative phenomena have proved a major challenge for the countries involved. Due to the recent nature of inter-ethnic conflicts, cross-border cooperation was (and remains) weak, with border infrastructure serving mainly in defence and control. Therefore, policy is limited in practice by such decisive factors in operation as the mentality, attitudes, ideologies and habits of the population along the border. It is not rare for border controls to be considered a parallel source of illegal earnings. In these conditions, almost no attention at all is paid to cross-border cooperation. Security aspects have remained the primary element of border policies that have become very tangible national issues in non-integrated 
(EU) countries. During EU negotiations, Slovenia had to step up its border controls, guided by EU regulations in this field, in particular with Croatia, with which the border at the time constituted an external frontier of the EU. But the country had different experiences with other states, with Italy and Austria serving as examples of very open political boundaries and well-developed cross-border relations. Slovenian-Italian border relations are only formalised practices.

Croatia's borders with Bosnia and Herzegovina are specific. The entire northern sector is associated with the River Sava as an obvious natural obstacle or even barrier, despite the presence of some border cities. It is the Bosnian Serb entity that is present over on the other side, so the conflicts of the near-past ensure that the level of cross-border connectivity remains very modest indeed. A passive border follows on in the western sector, visa-vis the Muslim Bosnian population in B\&H, while the former areas of the Serbian rebel para state (Krajina) are today emptied and entirely marginalised. In the south, where the border is with western Herzegovina, an ethnically homogeneous Croatian territory extends. Moreover, nearly half of all Bosnian Croats have dual citizenship. Between Serbia proper and Croatia the border is demarcated by the Danube. Serbia engages in lively cooperation with Bosnia and Herzegovina along the border in the valley of the Drina, given that it is a Serbian entity that is present over on the other side. Where the borders with Kosovo are concerned, except in the area of the ethnic-Serb Northern Kosovo. Among the Albanian territories (Albania, Kosovo and Western Macedonia), a quiet, informal process of integration into a single (large) Albanian state is in fact taking place (Zupančič 2014: 154). This further helps the construction of two legs of highways leading to the gateway of Otranto on the Adriatic. Finally, the Greek-Macedonian border is burdened by poor political relations between these two countries, notwithstanding the fact that Greece is at the same time Macedonia's most important economic partner.

\section{Conclusion}

Over the wide geographical area of 'Europein-between' (between the Baltic and the Mediterranean), the recent period of systemic transition was associated with dynamic processes of territorial fragmentation, associated with ethnic factors on the one hand, and trends towards integration (into the EU and NATO) on the other. The current political map offers a mosaic picture of almost all conceivable international positions and situations, leaving this space of European rimland facing new challenges. This place is an economically and demographically weak part of Europe, due to political fragmentation and modest military power, as set against the exposed pretensions of Russian geopolitics and Turkish neo-osmanic aspirations. Although these are distinctly opposite forces, they combine to have synergistic, and of course mostly negative effects.

Given the above geopolitical relations pertaining between countries and powers in the region between the Baltic and the Mediterranean Sea, it is possible to point to several types of borders present in the region. Generalising up to a point, and keeping in mind that, in principle, the presence of any delimitation and the setting of rules for its crossing are separate issues, there are three types of borders in the region presented. The first group includes borders between Member States of the European Union, i.e. the PolishLithuanian border, the borders between Lithuania, Latvia and Estonia, and the borders between Croatia, Slovenia and Hungary. They are characterized by a lack of border controls and a high level of ease of crossing for citizens of the EU at least. Variations on this theme are the borders of Bulgaria, Croatia and Romania, which are of course EU states, but which do not yet belong to the Schengen area. The second group includes borders that are at the same time the eastern frontier of the EU - with Russia, Belarus, Ukraine and Moldova. Here, those seeking to cross experience varying degrees of difficulty, with much depending on the bilateral relations that pertain. Thanks to international agreements, it is much easier 
to cross the Polish-Ukrainian border than the Polish-Belarusian border. A similar situation applies to the Moldovan-Romanian border. A third group comprises borders between states emerging from the former Yugoslavia, which can be divided into two sub-categories of borders with what are now Member States of the EU, i.e. Croatia and Slovenia; as well as borders with other countries arising after the breakup of Yugoslavia, also adding in Albania.

Ongoing territorial fragmentation remains possible over this region, with the most vulnerable countries being in the core of the Balkan Peninsula, along with Ukraine. However, it is also possible to anticipate certain unification processes, particularly in Albanianpopulated areas, but also in those inhabited by Serbs and Romanians.

Idealised political views, holding that enlargement of the EU would be a key premise underpinning economic, cultural and military security, have proved entirely illusory. Brexit indicates like nothing else how enlargement of the EU may already have gone as far as it can go, and if the EU as a political entity wants to survive at all, it may well need

\section{References}

BANAC I., 2006. The politics of ethnic homogenity [in:] War and change in the Balkans: Nationalism, conflict and cooperation. Cambridge: Cambridge University Press, pp. 30-43.

BARWIŃSKI M., 2013. Polish interstate relations with Ukraine, Belarus and Lithuania after 1990 in the context of the situation of national minorities. European Spatial Research and Policy, vol. 20, no. 1, pp. 5-26.

BieńCZYK-Missala A., 2016. Poland's foreign and security policy: Main directions. Journal Revista UNISCI, no. 40, pp. 101-117.

Brown M.E., Coté O.R., Lynn-Jones S.M., MillER S.E., 2001. Nationalism and ethnic conflict: Revised edition. Cambridge MA: MIT Press.

Bufon M., Minghi J., PaAsI A. (eds.), 2014. The new European frontiers: Social and spatial (re) to engage in radical reform of its economic, regional and cultural policies. Underestimation of lingering European nationalism is dangerous, so cultural and other policies will need to pay much more attention to it. It is necessary for policies based around cooperation, rather than integration, to take hold in areas in the vicinity of Russia and Turkey, as well as in the non-integrated Balkan core. This will - should - have a significant impacts on future border policies along the eastern edge of the European rimland. Border control does not mean closure, but must denoted greater selectivity, as well as a cooperative approach. In this context, what are of particular importance are solutions for bilateral cooperation along external as well as internal borders. The large number of labour migrants from the $\mathrm{CIS}$ countries into Poland and the EU, as well as from Poland and Romania to other EU countries, represent a crucial political issue. Further challenges to development and integration are posed by the presence of nationals of non-EU countries, by the existence of minorities in many EU Member States, and above all by the presence of the Russian community in the Baltic States.

integration issues in multicultural and border regions. Newcastle upon Tyne: Cambridge Scholars Publishing.

Conversi D., 2007. Homogenisation, nationalism and war: Should we still read Ernst Gellner?. Nation and Nationalism, vol. 13, no. 3, pp. 371-394.

BuRg S.L., Shoup S.P., 2000. The war in Bosnia and Hercegovina: Ethnic conflict and international intervention. New York: M.E. Sharpee.

Crampton R.J., 1997. Eastern Europe in the twentieth century and after. San Francisco: Routledge.

Czempiel E.O., 2003. Weltpolitik in Umbruch: Die Pax Americana, der Terrorismus und die Zukunft der Internationalen Bezeichnungen. München: Beksche Reihe.

Derlaga A., Wendt J., 2006. Cross-border co-operation between the Republic of Romania, Ukraine and Moldova [in:] J. Kitowski (ed.), Regional 
transborder co-operation in countries of Central and Eastern Europe - a balance of achievements, Geopolitical Studies, no. 14, Warsaw: Institute of Geography and Spatial Organization, Polish Academy of Sciences, pp.141-158.

DudzińSKa K., Dyner A.M., 2013. Mały ruch graniczny między obwodem kaliningradzkim a Polska - wyzwania, szanse, zagrożenia. PISM Policy Paper, no. 29 (77), pp. 1-6.

Eastern Borders. Annual Overview 2012, Warsaw: Frontex.

Ganster P., Lorey D.E, (eds.), 2005. Borders and border politics in a globalized world. Lanham: Rowman \& Littlefield Publishers.

Gerolymatos A., 2002. The Balkan Wars: Conquest, revolution, and retribution from the Ottoman era to the twentieth century and beyond. New York: Basic Books.

GILPIN R., GILPIN J.M., 2001. Global political economy: Understanding the international economic order. Princeton-Oxford: Princeton University Press.

Hobsbawm E.J., 2004. Nationen und Nationalismus: Mythos und Realität seit 1780. Frankfurt am Main: Campus Verlag.

Horowitz D.L., 2002. The deadly ethnic riot. Oakland: University of California Press.

Hupchick D.P., Cox H.E., 2001. The Palgrave concise historical atlas of Eastern Europe. New York: Palgrave

Ilieș A., Wendt J., Grama V., 2007. Cross-border co-operation between Romania and Bulgaria before EU enlargement [in:] M. Koter, K. Heffner (eds.), Regions in the process of European integration, Łódź-Opole: Region and Regionalism, no. 8, vol. 2, pp. 27-38.

Ilieș A., Wendt J.A., Ilieș D.C., Grama V., 2011. Structures and typology of the Romanian borderland [in:] K. Heffner (ed.), Historical regions in the structures of European Union. Historical division of the territory in Central Europe and in different states of the world, Łódź-Opole: Region and Regionalism, no. 10, vol. 2, pp. 117-131.

ILIEȘ A., WeNDT J.A., 2014. The evolution of historical regions and borderlands (1916-2011) at the northern Romanian Ukrainian border [in:] M. Bufon, J. Minghi, A. Paasi (eds.), The new European frontiers: Social and spatial (re)integration issues in multicultural and border regions, Newcastle upon Tyne: Cambridge Scholars Publishing, pp. 289-303.

KING C., 2000. The Moldovans. Romania, Russia and the politics of culture. Stanford: Hoover Institution Press.

LINK W., 1998. Die Neuordnung der Weltpolitik. Grundprobleme globaler Politik zum 21. Jahrhundert. München: C.H. Beck Verlag.

NaCEWSKA-TWARDOWSKA A., 2015. Wpływ sankcji rosyjskich na wymianę towarowa Polski. Prace Naukowe Uniwersytetu Ekonomicznego we Wrocławiu, no. 204, pp. 220-230.

PARKer G., 1997. Zahodna geopolitična misel v 20. stoletju. Ljubljana: Fakulteta ta družbene vede.

PIRJEVEC J., 2003. Jugoslovanske vojne 1991-2001. Ljubljana: Cankarjeva založba.

RUCH GRANICZNY ORAZ WYDATKI CUDZOZIEMCÓW W POLSCE, 2016. Warszawa: GUS, http://stat.gov.pl/ obszary-tematyczne/ceny-handel/handel [2 September 2017].

SebeSTYen V., 2009. Revolution 1989: The fall of the Soviet empire. London: Phoenix.

TANner M., 1997. Croatia A nation forged in war. New Haven: Yale University Press.

TunjIĆ F., 2006. The 'Europe in Between' and the OSCE [in:] M. Bufon, A. Gosar, S. Nurković, A.L. Sanguin (eds.), The western Balkans: A European challenge: On the decennial of the Dayton peace agreement, Koper: Založba Annales, pp. 151-178.

VÖCKLER K., 2008. Prishtina is everywhere. TurboUrbanismus als Resultat einer Krise. Leipzig: Parthas Verlag.

WENDT J., 2001. The geopolitical aspects of transit in Central Europe [in:] M. Antonsich, V. Kolossov, M.P. Pagnini (eds.), On the centenary of Ratzel's Politische Geographie Europe: Between political geography and geopolitics: Proceedings of the international meeting (Trieste, Italy, Wedsdnesday 10th-Saturday 3th December 1997), Roma: Societa Geografica Italiana, pp. 651-659.

WendT J., 2002. Diffusion du processus démocratique de l'Union Européenne à l'Europe centrale: comparaison de la Pologne et de la Roumanie. Mosella, vol. 27, no. 3-4, pp. 53-58.

WENDT J., 2004. Przestrzenne zróżnicowanie i uwarunkowania przenikania systemu demokratycznego w Polsce i w Rumunii. Warszawa: Carta Blanca. 
WENDT J., 2010. Changes on East neighbors tourism in Poland [in:] J. Wendt (ed.), Chosen problems of geographical research in Poland and Romania, Oradea: EUO, pp. 9-16.

Wendt J., Ilieș A., 2004. Kaliningrad: Region de menace ou de cooperation? [in:] Y. Richard, A.L. Sanguin (eds.), L'Europe de l'Est quinze ans apres la chute du mur, Paris: L'Harmattan, pp. 35-40.

WHITE G.W., 2007. Nation, state and territory: Origins evolutions and relationship. Vol, 1. Lanham: Rowman \& Littlefeld.

ZUPANČıČJ., 2005. Vloga in pomen narodnih manjšin $v$ čezmejnem sodelovanju. Primer manjšin $v$
Sloveniji in Slovencev $v$ sosednjih državah. Razprave in gradivo, vol. 47, pp. 26-41.

ZUPANČıČ J., 2009. Političnogeografska analiza Balkana. Dela, vol. 32, Ljubljana, pp. 85-134.

ZUPANČIČ J., 2014. Geopolitične perspektive srbskega vprašanja na Balkanu. Dela, vol. 40, Ljubljana, pp. 133-162.

ZUPANČIČ J., 2015. Crisis urbanization and empty spaces: The spatial aspects of ethnic conflicts [in:] Ethnic conflicts and global interventions, New York: Nova Publishers, pp. 21-41. 